\title{
Extending the Osmometer Method for Assessing Drought Tolerance in Herbaceous Species
}

\author{
Robert J. Griffin-Nolan \\ Colorado State University \\ Troy W. Ocheltree \\ Colorado State University \\ Kevin E. Mueller \\ Cleveland State University, k.mueller89@csuohio.edu \\ Dana M. Blumenthal \\ USDA Agricultural Research Service \\ Julie A. Kray \\ USDA Agricultural Research Service
}

Follow this and additional works at: https://engagedscholarship.csuohio.edu/scibges_facpub

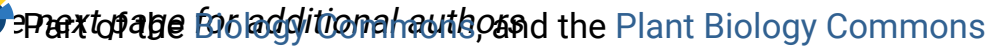

How does access to this work benefit you? Let us know!

Publisher's Statement

"The final publication is available at Springer via http://dx.doi.org/10.1007/s00442-019-04336-w

\section{Recommended Citation}

Griffin-Nolan, Robert J.; Ocheltree, Troy W.; Mueller, Kevin E.; Blumenthal, Dana M.; Kray, Julie A.; and Knapp, Alan K., "Extending the Osmometer Method for Assessing Drought Tolerance in Herbaceous Species" (2019). Biological, Geological, and Environmental Faculty Publications. 103.

https://engagedscholarship.csuohio.edu/scibges_facpub/103

This Article is brought to you for free and open access by the Biological, Geological, and Environmental Sciences Department at EngagedScholarship@CSU. It has been accepted for inclusion in Biological, Geological, and Environmental Faculty Publications by an authorized administrator of EngagedScholarship@CSU. For more information, please contact library.es@csuohio.edu. 
Authors

Robert J. Griffin-Nolan, Troy W. Ocheltree, Kevin E. Mueller, Dana M. Blumenthal, Julie A. Kray, and Alan K. Knapp 


\title{
Extending the osmometer method for assessing drought tolerance in herbaceous species
}

\author{
Robert J. Griffin-Nolan ${ }^{1,2} \odot$. Troy W. Ocheltree ${ }^{2,3} \cdot$ Kevin E. Mueller $^{4} \cdot$ Dana M. Blumenthal $^{5} \cdot$ Julie A. Kray ${ }^{5}$. \\ Alan K. Knapp $p^{1,2}$
}

\begin{abstract}
Community-scale surveys of plant drought tolerance are essential for undersianding seni-arid ecosystems and community responses 10 climate change. Thus, there is a need for an accurate and rapid melhodology for assessing drought tolerance strategies across plant lunctional types. The osmometer melhod for predicting leal osmotic potential at full turgor $\left(\pi_{0}\right)$, a key metric of leaf-level drought tolerance, has resulted in a 50-bold increase in the measurenent speed of this trail; however, the applicability of this method has only been tested in woody species and crops. Here, we assess the osmoneter method for use in herbaceous grassland species and test whether $\pi_{0}$ is an appropriate plant trait for understanding drought strategies of herbaceous species as well as species distributions along climate gradients. Our model for predicting leaf turgor loss point $\left(\pi_{\mathrm{TLP}}\right)$ from $\pi_{\mathrm{o}}\left(\pi_{\mathrm{TLP}}=0.80 \pi_{0}-0.845\right)$ is nearly identical to the model previously presented for woody species. Additionally, $\pi_{\mathrm{c}}$ was highly correlated with $\pi_{\mathrm{ILP}}$ for graminoid species $\left(\pi_{\mathrm{t} \mid \mathrm{p}}=0.944 \pi_{0}-0.611 ; r^{2}=0.96\right)$, a plant functional group previously flagged for having the potential to cause erroneous measurements when using an osmometer. We report that $\pi_{0}$, measured with an osmometer, is well correlated with other traits linked to drought tolerance (namely, leaf dry matter content and leat vulnerability to hydraulic failure) as well as climate extremes linked to water availability. The validation of the osmometer method in an herb-dominated ecosystem paves the way for rapid community-scale surveys of drought tolerance across plant functional groups, which could improve trait-based predictions of ecosystem responses to climate change.
\end{abstract}

Keywords Osmotic potential - Climate change - Grasslands - Plant traits - Drought

\section{Introduction}

Accurate and eflicient quantification of drought tolerance within plant conmunities is needed given that water is a primary limiting resource for plants across much of the world (Knapp el al. 2017) and extreme droughts are expected to become more conmon with climate change (Dai 2011; 2013; IPCC 2013). The response of ecosysiem processes, such as aboveground net primary produclivity, to drought has been shown to vary anong ecosystems (Huxman el al. 2004), cven within the sance bione (Knapp et al. 2015); however, a mechanistic understanding of this variability is lacking. Hydraulic traits, such as leat turgor loss point and xylem vulnerahility to cavitation, can provide a mechanistic understanding of plant growth and survival as well as community assembly in response to water stress (reviewed by Reich 2014). When scaled up from measurements of individual plants and species, such traits may provide useful information regarding responses of communities and 
coosystems 10 climate change (Suding el al, 2008). Un forlunately, hydraulic traits are infrequently measured in community-scale trail surveys (Grillin-Nolan el al. 2018), likely due to the time-intensive measurenent protocols they requite (Sack ce al. 2002; Brodribb and Holbrook 2003); (hus, a key research need is the identilication and validation of rapid, high-throughput methods for assessing drought tolerance that can be applicd within and across plant functional lypes.

Leaf turgor loss point $\left(\pi_{\mathrm{TLP}}\right)$, the leaf water potential at which average cell turgor is lost and leaf wilting occurs, provides a wealth of physiological information pertaining to cell wall integrity, stomatal closure and, more generally, the extent to which plants can maintain metabolism as soil dries (Kramer and Boyer 1995; Bartlett et al. 2016; Meinzer et al. 2016). Given this and the strong correlation between $\pi_{\mathrm{ILP}}$ and water availability both within and between biomes, $\pi_{\text {TL.P }}$ is an ideal trait for assessing drought tolerance across broad spatial scales (Bartlett et al. 2012a). The traditional protocol for quantifying $\pi_{T . P}$, pressure-volume $(p-v)$ curves, requires a lengthy procedure (up to 2 days to produce curves for 4-6 leaves) which greatly limits the number of species or locations that can be viably surveyed. Fortunalely, $\pi_{\mathrm{TL} . \mathrm{P}}$ can be estimated from leat osmotic potential at full turgor, the conponent of water potential related to eellular solute concentration and a strong decerninant of $\pi_{T T}$ (Barlell cl al. 2012a). I cal osmotic potential at full turgor $\left(\pi_{0}\right)$ is typically quantilicd trom $p$-v curves as well; however, Barled el al. (2012b) recently described a method for rapidly measuring $\pi_{0}$ using a vapour pressure osmometer. The method has resulted in a 30-10 50-fold increase in the measurenent speed of $\pi_{T L P}$ and has since been used to quantify community-scale drought tolerance in tropical rainforests (Marechaux ct al. 2015). Since its publication, the osmometer methor, and the linear model for predicting $\pi_{\mathrm{TLP}}$ from $\pi_{0}$, have exclusively heen used in ecosystems dominated by woody species (Marechaux et al. 2015; Esperon-Rodríguez et al. 2018) or crops (Mart et al. 2016) and has yet to he validated in herbaceous plant communities, such as grasslands. Indeed, several studies have cautioned that osmometer estimates of $\pi_{0}$ may prove inaccurate for leaves with dense large vein networks or thin leaves with large midrih veins (i.e. grass leaf blades) as the inclusion of such veins in tissue sampling may lead to apoplastic dilution (Kikuta and Richter 1992; Marechaux et al. 2016); thus, testing of the osmometer method within grasslands including such species is needed.

The grassland biome covers more than $30 \%$ of Earth's terrestrial surface and provides valuable ccosystem services such as carbon storage, soil stabilization, forage production, and wildlife habilat (Noy-Meir 1973; Ficld el al. 1998). Given that most grasslands are water-limited, they are an idcal study system for surveying drought tolerance and responses to future changes in Farth's hydrologic cycle (IPCC 2013). Here, we focus on grasslands of the American
Greal Plains, a region characterized by highly variable precipitation and a high frequency of climate extremes such as drought and flooding (Kunkel el al. 2013). Water availability will likely becone more variable in this region as some of these grasslands are expected 10 experienee more frequent "dust-bowl"-like conditions by the end of the century (Karl et al. 2009).

We conducted a survey of drought tolerance traits of conmon herbaceous plant species across three North American grasslands to address two main goals. First, we test the validity of the osmometer method (Bartlett et al. 2012b) for use on herbaceous plant species. Validation of this method will encourage community-scale surveys of drought tolerance across plant functional types, especially within a relatively drought-sensitive region (i.e. grasslands; Huxman et al. 2004; Knapp et al. 2015), as well as address recent concerns of scientific reproducibility (Baker 2016). Second, we assess the mechanistic value of $\pi_{0}$ as a drought tolerance trait in grasslands. A central goal of trait-based ecology is to make generalized predictions of large-scale phenomenon (c.g. community assembly, mutrient cycling, dynamics of net primary production) using the composite traits of interacting organisms within a community (Shipley el al. 2016). Established links between species distributions, performance, and physiological traits are thus required, yer oflen diflicult to identily (Paine el al. 2018). To this end, we test the hypothesis that $\pi_{1}$, will be correlated with other mechanistic traits commonly used to describe leaf-level drought tolerance, namely leaf dry matter content (I.DMC) and leal vuluerability to hydraulic railure (Brodribb 2017). Additionally, we define the climatic extrenes of species distributions and test the hypothesis that $\pi_{0}$ is positively correlated with water availability (i.e. species with more negative $\pi_{0}$ will predominately inhabit arid regions) (Bartlett et al. 2012a). The degree to which this correlation is driven by the driest or wettest extreme of a species distrihution will highlight the relative influence of ahiotic stress tolerance (i.e. waterlimitation) or biotic stress tolerance (i.e. competition with more resource-acquisitive species), respectively, in controlling $\pi_{0}$ of herbaceous species.

\section{Materials and methods}

\section{Plant material}

We collected nine species of graminoids and ten species of forbs/subshrubs (non-woody) fron three native grassland sites (predoninatcly mixed-grass prairic) across Wyoming and Kansas during mid-summer 2015 (Table 1). Six plant samples, including soil and a portion of the root system, were uncarthed at each sitc, placed in a reservoir of water, and covered with large plastic bags ( $n=6 \mathrm{pots} / \mathrm{species} / \mathrm{sit}$ ). 
Table 1 Herbaceous species surveyed in this slukly are shown along with collection siles. Functional lype, and Irail means (SE). Trails include osmolic polential estimaled lrom boub an osmoneler $\left(\pi_{0} \mathrm{osm}\right)$

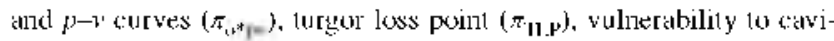

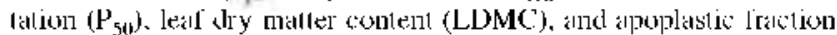
$\left(a_{j}\right)$

\begin{tabular}{|c|c|c|c|c|c|c|c|c|c|}
\hline Species & Code & Collection sile & Functiomal 1 ypex & $\pi_{0} \operatorname{cim}\left(\mathrm{MP}_{\mathrm{a}}\right)$ & $\pi_{1, *} p_{i}\left(M^{\left.k_{1}\right)}\right)$ & $\pi_{11 . p}\left(\mathrm{MP}^{\left.k_{1}\right)}\right.$ & $\mathrm{P}_{50}\left(\mathrm{MP}_{\mathrm{c} 1}\right)$ & LDMC & $A_{1}$ \\
\hline Andropogen seromiti & ANGE & $\mathrm{KN} Z$ & Graminukl (C4 yläs) & $-1.2(0.01)$ & $-1.2(0.04)$ & $-1.7(0.06)$ & -1.1 & 0.32 & 0 \\
\hline Bontelones artipendsha & $\mathrm{BCY} \mathrm{C}$ & HYS & Graninuil (C4 yläss) & $-1.8(0.07)$ & $-1.8(0.11)$ & $-2.5(0.08)$ & -1.6 & 0.45 & 0.37 \\
\hline 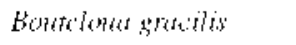 & BCKOK & HYG & Graminuik (C) y grass) & $-1.3(0.02)$ & $-1.7(0.09)$ & $-2.3(0.12)$ & -1.1 & 0.46 & 0.16 \\
\hline Sorghesstrom nstoms & SONU & $\mathrm{KN} Z$ & Graminuik (C4 yläss) & $-0.9(0.08)$ & $-1.2(0.06)$ & $-1.6(0.03)$ & -0.8 & 0.32 & 0.10 \\
\hline sporoloolstis esper & SPAS & HYS & Graminulel (C'4 grass) & $-1.8(0.12)$ & $-1.6(0.06)$ & $-2.3(0.12)$ & -2 & 0.41 & 0.11 \\
\hline 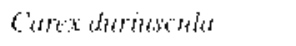 & C.ADU & $\mathrm{HPC}$ & Graminuik (C 3 selelge) & $-2.7(0.10)$ & $-2.7(0.16)$ & $-3.2(0.19)$ & -1.4 & 0.41 & 0.17 \\
\hline Hesporostipa comestes & HECO & $\mathrm{HPC}$ & 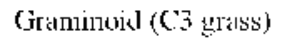 & $-2.2(0.06)$ & $-2.2(0.08)$ & $-2.7(0.13)$ & -2.3 & 0.44 & 0.39 \\
\hline 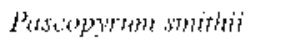 & PASM & $\mathrm{HPC}$ & Graminukl (C 3 glass) & $-1.7(0.02)$ & $-1.6(0.04)$ & $-2.0(0.07)$ & -1.8 & 0.38 & 0.20 \\
\hline Poustertala & POSE & $\mathrm{HPC}$ & Graminuil (C? glass) & $-1.7(0.11)$ & $-1.5(0.04)$ & $-2.1(0.12)$ & - & 0.32 & 0.33 \\
\hline $\begin{array}{l}\text { Lemeramem monta- } \\
\text { nsm }\end{array}$ & LEMO & $\mathrm{HPC} \mathbf{j}$ & Monocul (lorb) & $-1.3(0.06)$ & $-0.8(0.06)$ & $-1.2(0.11)$ & - & 0.18 & 0.65 \\
\hline Astrugelnes dromenemdit & ASLK & $\mathrm{HPC}$ & Dicol (lorb) & $-0.7(0.08)$ & $-1.1(0.12)$ & $-1.5(0.12)$ & - & 0.24 & 0.58 \\
\hline Astreseshes lestrumemi & ASLA & $\mathrm{HPG}$ & Dicol (lorb) & $-1.0(0.13)$ & $-1.7(0.09)$ & $-2.2(0.10)$ & - & 0.26 & 0.26 \\
\hline Astresethes shortionss: & $\mathrm{ASSH}$ & $\mathrm{HPC}$ & Dicol (lorb) & $-0.7(0.07)$ & $-0.7(0.11)$ & $-1.0(0.15)$ & - & 0.17 & 0.76 \\
\hline Linaria dolmatios & LIDA & $\mathrm{HPC}$ & Dicol (lorb) & $-0.6(0.16)$ & $-1.0(0.09)$ & $-1.3(0.10)$ & -0.4 & 0.14 & 0.36 \\
\hline Hertonses lamitolates & MELA & $\mathrm{HPC}$ & Dicol (lorb) & $-0.9(0.06)$ & $-1.2(0.08)$ & $-1.5(0.05)$ & -0.5 & 0.21 & 0.19 \\
\hline Penutemen alloidas & PEAL & $\mathrm{HPC}$ & Dicol (lorb) & $-0.6(0.01)$ & $-1.3(0.14)$ & $-1.6(0.13)$ & -1.3 & 0.27 & 0.18 \\
\hline 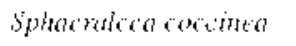 & SPCO & $\mathrm{HPG}$ & Dicol (lorb) & $-1.0(0.04)$ & $-1.4(0.13)$ & $-1.4(0.15)$ & -1.8 & 0.3 & 0.41 \\
\hline Artomistes frigedes & ARFK & $\mathrm{HPG}$ & Dicul (subshrub) & $-1.4(0.04)$ & $-1.1(0.04)$ & $-1.5(0.04)$ & - & 0.35 & 0.50 \\
\hline Eriogement thospen & EREF & $\mathrm{HPC}$ & Dicol (subshrub) & $-0.6(0.08)$ & $-1.1(0.07)$ & $-1.5(0.11)$ & - & 0.32 & 0.48 \\
\hline
\end{tabular}

"Collection sites include a northern mixed-grass prairic (High Plains Grassland Rescarch Center. HPC: mean annual precipitation

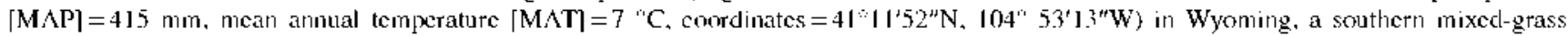

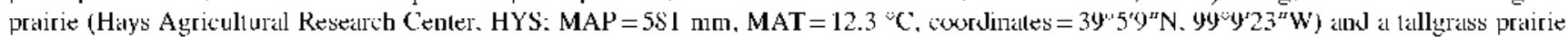

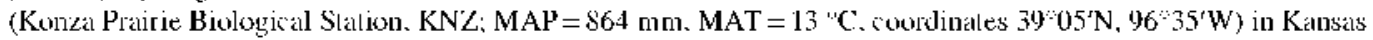

Plants were left in the dark for $\sim 12$ h to allow leaves to fully rehydrate prior $10 p-y$ curve determination and osmoneler measurements.

\section{Osmometer method validation}

Pressure-volume curves were measured on one leaf per plant sample ( $n=6$ leaves/species) using the hench drying method (Schulte and Hinckley 1985). A recently expanded mature leaf was wrapped in parafilm wax and cut near the leaf base (parafilm was weighed and subtracted from suhsequent leaf weight measurements). Immediately after cutting, the leat was placed in a Scholander-style pressure chamber (PMS Instruments, Albany, OR, USA) to measure leaf xylem water potential ('P $\mathrm{P}_{\text {teat }}$ ). Following water potential determination, the leat and parafilm were weighed on a micro-balance ( $\pm 0.1 \mathrm{mg}$, Ohaus Pioncer; Ohaus Corporation, Parsippany, NJ, USA). The leal was then sealed in a plastic bag and placed in a dark drawer to allow slow dehydration. This process was repeated approximately 10 times for each leaf or until ' $\Psi_{\text {lear }}$ reached $-4 \mathrm{MPa}$. The leat was then rehydrated, scanned for leaf area at 300 dpi (Fpson Perlection V600, Fpson America Inc., I.ong Beach, Ca, USA), dricd for $48 \mathrm{~h}$ at $60^{\circ} \mathrm{C}$ and weighed. Ical area was calculated using InageJ soltware (htlps://magej.nih.gov/ij/). Turgor loss point $\left(\pi_{\mathrm{TLP}}\right)$, osmotic potential at full turgor $\left(\pi_{0^{*} \mathrm{pv}}\right)$ and leaf capacitance $\left(C_{\text {lent }}\right)$ were calculated for 5-6 leaves following standard methods (Turner 1988; Koide et al. 1989) and averaged for each species. Fresh weight of hydrated and oven-dried leaves was used to calculate LDMC ( $\mathrm{g}$ dry mass $\mathrm{g}^{-1}$ fresh mass).

Within 24 h of $p-v$ curve determination, osmotic potential at full turgor was also estimated using a vapour pressure osmometer $\left(\pi_{0} *_{0 \text { sim }}\right)$ (VAPRO 5520 vapour pressure osmometer, Wescor, Logan, UT), following Bartlett et al. (2012b). Six leaves per species were clipped underwater and fully hydrated overnight prior to measuring $\pi_{\left.00^{*}\right) \text {. }}$. A leaf disc was sampled from cach hydrated Icaf using a 5-nm biopsy punch (Miltex DP-5 num, Electrum Supply, FIkhart, IN), wrapped in tin foil, and submerged in liquid nitrogen for $\sim 60 \mathrm{~s}$ to lyse the plant cell walls. The leaf disc was generally taken toward the apical portion of the leat to avoid or minimize the sampling of large midrib veins, depending on leal width. Bartletl el al. (2012b) warn of potential inaccuracies likely 10 arise when using the osmoneter method on species with large midrib veins (c.g. grasses such as Sorghastrum nutans) 
as the synplastic solution may becone diluted by xylen water. When possible, the leal disc was laken from a portion of the lamina without any midrib present (c.g. species with broad leaves). For species with leaves (hat were narrower than our hiopsy punch, several leaves were aligned next to each other and the sample was taken across multiple leaves to ensure comparable disc sizes were sampled across species. Each disc was then punctured $\sim 15$ times using forceps to facilitate rapid equilibration in the osmometer chamber. Leat discs were quickly placed in the osmometer chamber following puncturing to minimize evaporation $(<30$ s between removal from liquid nitrogen and placement in osmometer chamber). Samples were left in the closed chamber for $\sim 10 \mathrm{~min}$ to allow equilibration. Measurements were then made every two minutes until osmolarity reached equilibrium ( $<5$ mmol kg ${ }^{-1}$ change in osmolarity between measurements). Osmolarity was then converted to osmotic potential at full turgor $\left(\pi_{1 *^{*}, w_{11}}\right)$ using the following equation: $\pi_{v * * \text { *strI }}=$ osmolarity $*-2.3958 / 1000$.

Barlete el al. (2012b) outline possible discrepancies in osmometer measurements that can arise due to the opposing effects of apoplastic dilution (which leads to overestimations of $\pi_{(, * \text {, sim }}$ ) and cell wall dissolution (which leads to underestimations of $\pi_{0^{*} \text { osm }}$ ). To account for such discrepancies, we calculated "predicled $\pi_{\mathrm{e}^{*} \mathrm{esm}}$ " lollowing a model presented by Bartlel el al. (2012b) which includes estimates of these effects:

$$
\begin{aligned}
\pi_{\mathrm{o} * \mathrm{predicted}}= & \left(a \times \pi_{\mathrm{O} * \mathrm{p} v * \mathrm{af}}\right)+(b \times \mathrm{LDMC}) \\
& +\left(c \times \pi_{0 * \mathrm{p} v * \mathrm{af}} \times \mathrm{LDMC}\right)+d
\end{aligned}
$$

where, LDMC is a proxy for cell wall investment and thus dissolution, while $\pi_{0, *_{T} w^{*} ; I^{*}}$ is an estimate of osmotic potential at fill turgor (from $p-v$ curves) corrected for apoplastic dilu-

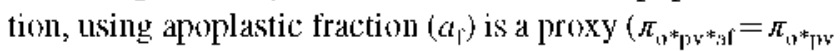
$\left.*\left(1-a_{f}\right)\right)_{1} p l$ curve estimates of $a_{i}$ were set to zero for one species (ANGE) as estimates were not signilicantly different from \%ro. A slope of 1 for the relationship between measured and predicted $\pi_{i, *_{1} \text { sim }}$ would indicate that accounting for apoplastic dilution and cell wall dissolution corrects this bias in osmonteter measurenients (Barllell cl al. 2012b).

\section{Leaf hydraulic conductance}

I.caf hydraulic vulnerability curves were produced for 12 of the 19 focal species, including both graninoids and forbs/subshrubs, following the rehydration kinctics method (Brodribb and Holbrook 2003). The methodology described here is for graminoids, as vulnerability curves for forbs, subshrubs, and one sedge (Carox duriuscula) were taken from previously collected data (Ocheltree in review). Several tillers, each with at least two recently emerged leaves of comparable size, were clipped from the rehydrated samples and placed on a bench 10 dry slowly. Drying time varied from $30 \mathrm{~s} 103 \mathrm{~h}$ depending on the species and the desired level of dehydration. Prior 10 hydraulic conductance measurements, the tiller was sealed in a plastic bag and placed in a dark drawer for 2-3 min to allow any water potential gradients across a single leat to equilibrate. The more apical leaf was removed from the stem with a razor and placed in a pressure chamber to determine initial leaf water potential $\left(\Psi_{0}\right)$. The second leaf was removed by cutting under filtered de-ionized water that had been de-gassed for $1 \mathrm{~h}$ and then rehydrated for a pre-determined amount of time (5-120s depending on $\left.\Psi_{0}\right)$. The leat was then re-cut slightly above the water line and placed in a pressure chamber to determine final rehydrated leaf water potential $\left(\Psi_{j}\right)$. Leaf hydraulic conductance $\left(K_{\text {le: }}\right)$ was then calculated using initial and final leaf water potential as well as average capacitance $\left(C_{\text {leas }} ; n=6\right)$ quantilied from $p$-v curves:

$K_{\text {leaf }}=\frac{C_{\text {leaf }} * \ln \left[\frac{\varphi_{0}}{\varphi_{\mathrm{f}}}\right]}{t}$

where $t$ is the rehydration tine in seconds. $K_{\text {leat }}$ was calculated for 30-40 leaves varying in hydration status and regressed agains1 $\Psi_{0}$. Maximum conductance $\left(K_{\max }\right)$ was estimated as the mean of the live highest values of $K_{\text {leat }}$ belween $\Psi_{0}$ of -0.5 and $-1 \mathrm{MPa}$. I cal hydraulic vulnerability curves were produced by fitting logarithmic, linear, exponential, and sigmoidal models to data binned and averaged to 0.5 MPa intervals and selecting the model with the lowest Akaike Information Criteria (AIC; see Tahle SI for AIC values). This model was used to calculate the leat water potential at which $K_{\text {leaf }}$ decreases to $50 \%$ of $K_{\max }$ (P50, in MPa). Vulnerability curves were made for a subset of graminoids in this study (Fig. Sl), while $\mathbf{P}_{50}$ values for forbs shruhs were taken from Ocheltree (in review).

\section{Bioclimatic envelopes}

Bioclimatic envelopes of temperature and precipitation were gencrated using the geographic range of each species. Spatial infornation on all reported occurrences of each species was downloaded from the Global Biodiversity Infornation Facility (GBIF; www.gbil.org). The number of reported occurrences ranged from 90 to 8259 with an average of 1193 occurrences/species. Clinatic data from the nearest $0.5-\mathrm{km}$ grid ecll of each reported occurrence were collected from the WorldClim database (hllp:/www.worldelin.org/biocl imi). Because GBIF data are spatially biased and one region can be over-represented in a dat a set (Beck et al. 2014), we subsanipled the climate data to remove this hias. If multiple occurrences fell within the same grid cell of climate data from WorldClim, that grid cell was only used once in our 
analysis. Further, the occurrenee data were liltered 10 remove any incorrect entries that reported occurrences in aguatic environments (i.e. larec bodics of water). We focused on variables including estimales of temperalure and precipitation seasonality as well as annual summaries of temperature and precipitation (see Table $\$ 2$ and the WorldClim database for a full list of climatic variables). The 5 th and 95 th quantiles of each variable were calculated from data compiled for all recorded occurrences to quantify bioclimatic envelopes that define the climatic extremes of a species" inhabited range. For example, the 5th quantile of "precipitation during the wettest month' represents the precipitation during the wettest month in the driest locations of a species range. These hioclimatic envelope parameters have heen shown to be more hiologically relevant than regional annual climate statistics (Ocheltree et al. 2016).

\section{Data analyses}

Univariate linear regression analyses were used 10 lest for

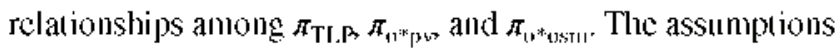
of linear regression (skewness, heleroscedasticity, elc.) were met for all models presented in this study. The slope and intereept of the models presented by Barlet et al. (2012b) were compared $1095 \%$ conlidene intervals (CI) of the slope and intereept of the nodels presented here. The PRFSS and RMSE statistics for all method comparison models are available in Table S3. The most parsimonious model for estimating hoth $\pi_{0^{d} \mathrm{py}}$ and $\pi_{\mathrm{TLP}}$ was determined hy calculating AICc values for linear mixed effects models including LDMC, $a_{f}$, $\pi_{0^{*} \text { osm }}$ and all possihle interactions as fixed effects (AICc values in Table $\$ 4$ ). Leaf osmotic potential at full turgor $\left(\pi_{0^{*} \mathrm{osm}}\right)$ was also regressed against $P_{50}$ and LDMC to investigate correlations among these functional traits. Traits of different plant functional types (graminoids vs. forh/suhshrub) were compared using $t$ tests. Additionally, hydraulic trait mean values from Bartlett et al. (2012h) were compared to the range of hydraulic trait values assessed in this study. Relationships hetween species-specific hioclimatic envelopes and $\pi_{\left.0^{*} * \mathrm{k}_{m}\right)}$ were also assessed using a Pearson's corrclation matrix ('cor' function in basc R). R statistical soltware version 3.4.4 was used ror all statistical analyses.

\section{Results}

\section{Osmometer method validation}

I.caf turgor loss poimt and osmotic potential at full turgor calculated from $p-v$ curves were highly correlated anong common herbaccous species within central US grasslands, with $96 \%$ of the variation in $\pi_{1 L P}$ explained by $\pi_{0^{*} \mathrm{pv}^{\mathrm{v}}}$ (Fig. 1 ). Additionally, $\pi_{\mathrm{o}^{*} \mathrm{p}^{\mathrm{w}}}$ was highly correlated with osmotic polential estimated from a vapour pressure osmometer $\left(\pi_{0^{*} \text { os } 11}\right)$ (Fig. 2), with the slope and intereept not signilicantly different from that presented by Barlell el al. (2012b); however, this model did diverge from a 1:1 relationship indicating some bias in osmometer measurements. Using Eq. 1, we tested whether the divergence from a 1:1 line in this method comparison could be explained by the opposing effects of apoplastic dilution and cell wall dissolution. The relationship between $\pi_{0^{*} \text { predicted }}$ and $\pi_{0^{*} \text { csm }}\left(r^{2}=0.78\right)$ did not differ significantly from a 1:1 relationship, indicating no bias after correcting for these factors (Fig. 3). Nonetheless, model selection for predicting $\pi_{0^{*} \mathrm{pr}}$ from all combinations of fixed effects ( $\pi_{1, * *_{1}+1,}, a_{f}$, and LDMC, plus interactions) selected a model with just $\pi_{0^{*}{ }_{u s m}}$ as the most parsimonious (AICc $=10.57$; Table S4) with the amount of variance explained only increasing by $13 \%$ with the inclusion of $a_{f}$ and I.DMC (plus interactions).

Icaf osmotic polential at full turgor measured with an osmoneter was highly correlated with leal turgor loss point across several common grassland species including graminoids, forbs and subshrubs (Fig. 4a). This lincar model for predicting $\pi_{T T . P}$ of predominantly herbaceous species is nearly identical 10 the woody species model presented by Barllelt el al. (2012b), with a minor oflsel for the $y$ inter$\operatorname{cept}(-0.21 \mathrm{MPa})$. Additionally, the slope and imereept of their model lall within the $95 \% \mathrm{CI}$ of the grassland model presented here. The strength of the grassland model was

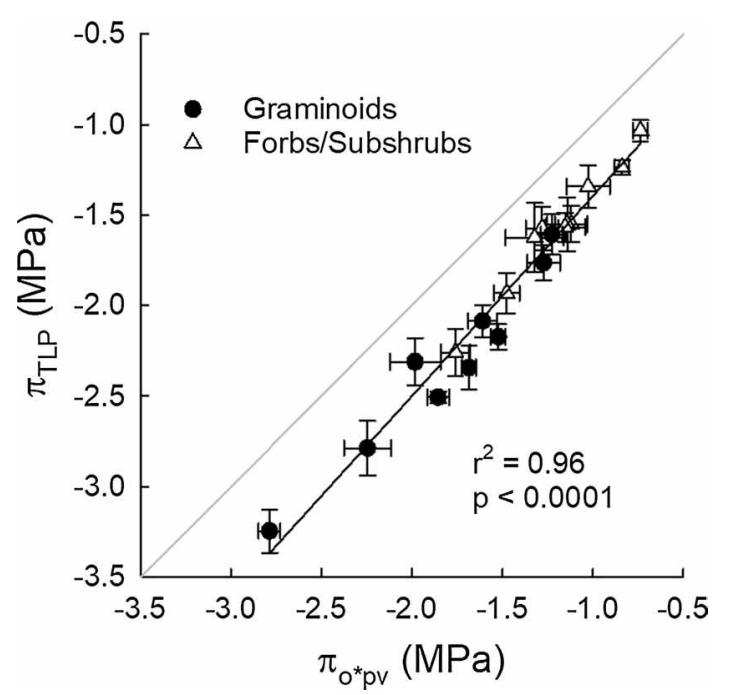

Fig. 1 I.caf turgor loss point is largely controlled hy leaf osmotic potential at full turgor, the component of leaf water potential determined by cellular solute concenlrations. A strong linear relationship belween osmotic potential at full lurgor $\left(\pi_{1, *}{ }^{*}\right)$ and osmolic polential al lurgor loss point $\left(\pi_{n}\right.$. $)$ eslimated from pressure-volume curves is shown for largely herbacoous grassland species including gramimoids, forts, and subshrubs. The hlack line represents this mondel:

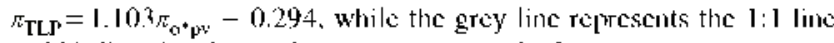
and bi-directional error bars represenl slandard error 


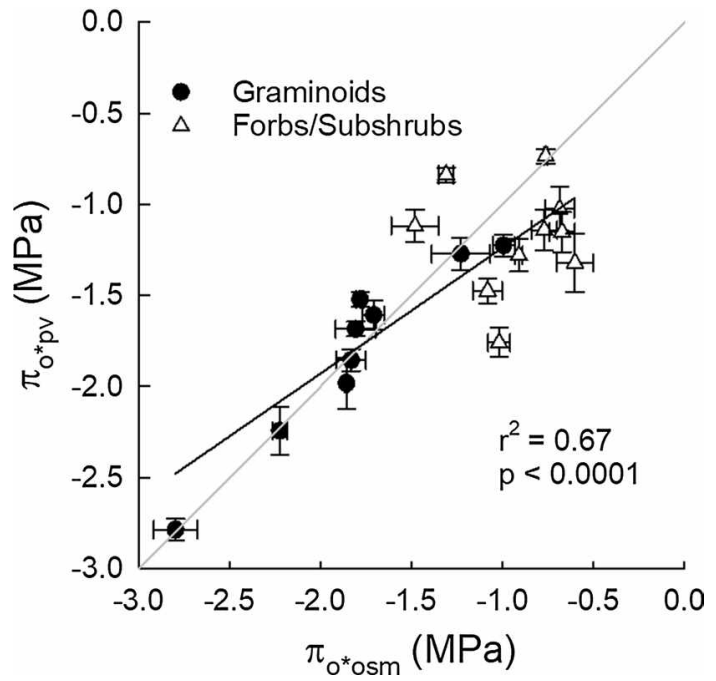

Fig. 2 Osmotic potential at full turgor measured with a vapour pressure osmometer ( $\pi_{0 \text { resm }}$ ) predicts that estimated from $p-b$ curves $\left(\pi_{1, *}\right)$ with a slight deviation liom the $1: 1$ line. The morlel

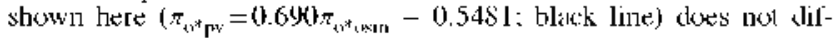
ler signilicanly from a sinilir moklel presented lor workly species $\left(\pi_{\mathrm{C}^{4} \mathrm{p}}=0.690 \pi_{\mathrm{S}^{4} \mathrm{OSm}}-0.548 \mathrm{1}\right.$ : Bartlett et al. $\left.2012 \mathrm{~h}\right)$ hased on the $95 \%$ CI of the slope $(0.45,0.92)$ and intercept $(-0.8954093$. -0.2007442 ). Graminoid species fall along the $1: 1$ line (grey line). while nuch of the scaller is slee to variability in lorbs/subshrubs. Bidirectional error bars represent standard error

improved when forbs and subshrubs were excluded, with $96 \%$ of the variation in graminoid $\pi_{\mathrm{TLP}}$ explained by $\pi_{\mathrm{v}^{*} \mathrm{vam}}$ (Fig. 4b)- this relationship also did not differ from that of Barllell el al. (2012b). Anong forbs/subshrubs, we did not observe a signilicant relationship between $\pi_{\mathrm{TLP}}$ and $\pi_{\mathrm{o}^{*} \mathrm{osm}}$.

\section{Mechanistic value of $\pi_{0}$}

We found significant differences in trait values hetween plant functional types (PFT; graminoids vs. forbs/suhshruhs). Graminoids had significantly lower pressure potential for all parameters ( $\pi_{\mathrm{TLP}}, \pi_{\mathrm{O}^{*} \mathrm{p}^{\mathrm{m}}}$ and $\pi_{\mathrm{v}^{*} \mathrm{csm}}$ ) than forbs/suhshrubs (Fig. 5), with this PFT difference similar in magnitude to the regional differences ohserved hy Bartlett et al. (2012b) hetween species sampled from a tropical forest site (annual rainfall $=1532 \mathrm{~mm}$ ) and a common garden near UCLA (annual rainfall $=450 \mathrm{~mm}$ ). These average differences between PFTs contributed substantially to the correlations between pressure potential parameters (c.g., $\boldsymbol{\pi}_{\text {TI.P }}$ and $\boldsymbol{\pi}_{4}$ ) among species (Figs. 1, 2, 3). Granninoid species also had significantly higher I.DMC compared to forbs/subshrubs (nican $=0.39$ and $0.25 \mathrm{gg}^{-1}$, respectively; $t$ lest, $p<0.001$ ). No statistical comparisons of $P_{50}$ across PFTs were lested due to the small sample size for forbs/subshrubs $(n=3$; Table 1).

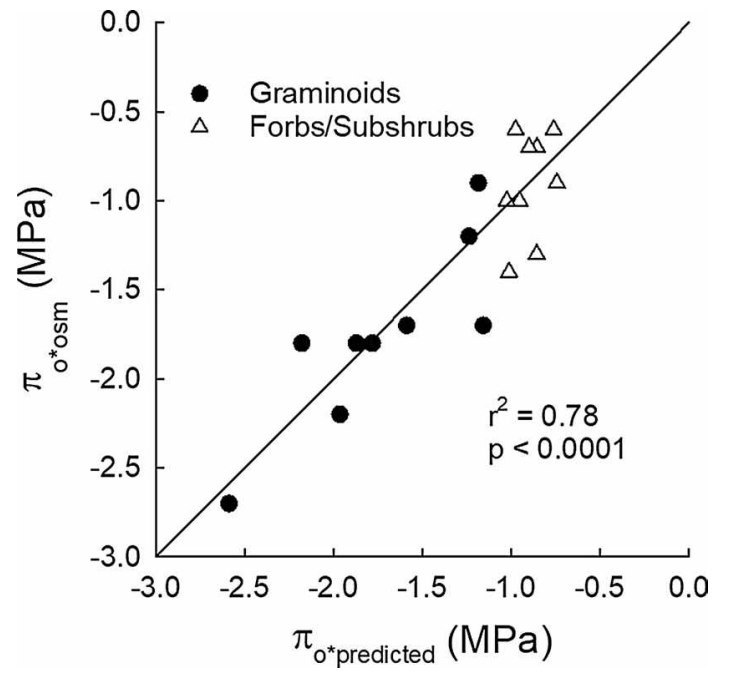

Fig. 3 Correcting for discrepancies that arise from osmometry (see the departure from the 1:1 line in Fig. 2), $\pi_{0 \text { inom }}$ was recalculated using Eq. 2 (1aken lrom Bartlet el al. 2012b). Osmonelry can leakl to over- and underestimations ol $\pi_{48}$ slue 10 apoplastic dilution and cell wall vissolution. respectively. Here predicted usnotic polential at full turgor $\left(\pi_{\text {orpredited }}\right)$ was calculated from a model that includes estimates of cell wall dissolution (leaf dry matter content as a proxy. I.DMC), apoplastic fraction, and their interaction. The fitted regres-

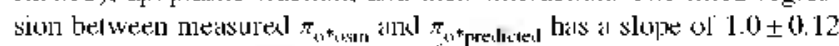

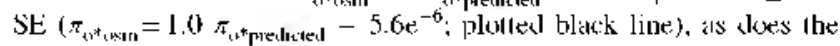
relationship including solely yraminoids (slopex $=0.9 \pm 0.23 \mathrm{SE}$ : see Talyle $S_{2}$ ), indicating no bias after correcting for these factors. The counterhalancing effects of apoplastic dilution and cell wall dissolution suggest the osmometer method is rohust for graminoid leaves (graminoids fall along the 1:1 line in Fig. 2); however, the net eflect of LDMC and a, should be considered for wher lypes of leaves.

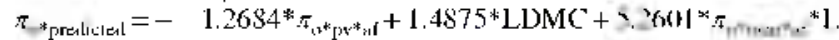
D)MC -1.2147

Osmometer estimates of leaf osmotic potential at full turgor were highly correlated with other hydraulic and morphological traits that are indicative of drought tolerance. Specifically, $\pi_{0^{*} \text { osm }}$ was positively correlated with vulnerability to hydraulic failure $\left(\mathrm{P}_{50}\right.$; see Fig. SI for vulnerahility curves), and negatively correlated with leaf dry matter content (LDMC), suggesting there may he coordination among leaf drought tolerance characteristics of these species (Fig. 6). Additionally, LDMC was negatively correlated with $\mathbf{P}_{50}\left(r^{2}=0.37 ; p=0.02\right)$.

The bioclimatic envelopes assessed in this study represent climatic boundarics of a species distribution with high and low quantiles indicating the climate extremes that species expericnces across their observed range. For graninoids, the bioclimatic envelope that explained the most variability in $\pi_{\left.1, *_{1}\right) \mathrm{Km}}$ was mean annual precipitation (MAP) at the weltest extremes (95th quantile) of a species distribution (Fig. 7; MAP $_{0,5 \mathrm{~h}}$ was also significantly correlated with $\pi_{00^{*} \mathrm{~T} w}$; $F^{2}=0.60$ ). This signilicant positive relationship indicates that $\pi_{0^{*} \text { osm }}$ was less negative for graninoid species that occupy 
(a)

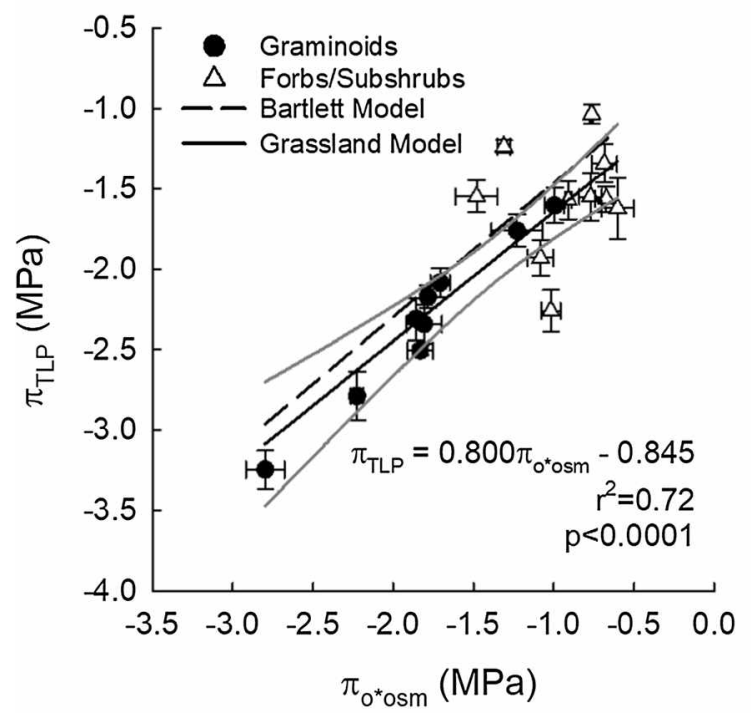

Fig. 4 A linear model for preclicting leaf turgor loss point ( $\pi_{\text {II. }}$ ) among grassland species using osmotic polential al full lurgor esti-

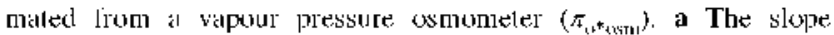

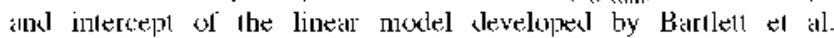
$\left(\pi_{\mathrm{tl}: \mathrm{l}}=0.832 \pi_{\mathrm{OSm}}-0.631\right.$; dashed line) falls within the $95 \% \mathrm{CI}$ of the slope $(0.5552126,1.046013 \mathrm{l})$ and intercept $(-1.2050772$, 0.4852862 ) of the grassland model shown here (black line; grey line represents the 95\% (1). The linear morlel equalion depicted on the ligure is for the grassland molel, which includes yraminoids. lorbs

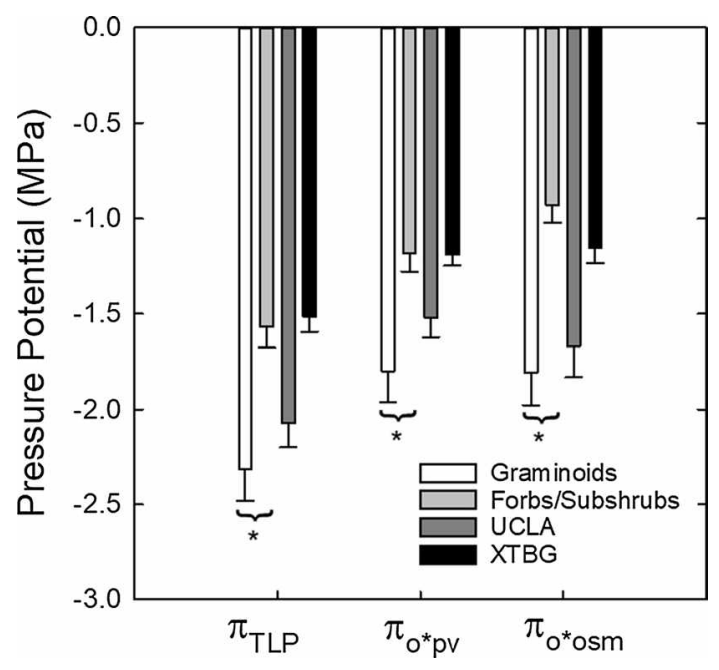

Fig. 5 Turgor loss poinl $\left(\pi_{n p}\right)$ and osmotic potential al full lurgor measured from pressure-volume curves $\left(\pi_{\mathrm{c}^{*}, p^{p}}\right)$ and a vapour pressure osmometer $\left(\pi_{0^{*}, 0 s m}\right)$ are shown grouped by plant functional type (graminoids and forhs/suhshruhs; meantSF). Forbs/subshrub s[ecies have signilisanlly higher pressure potenlials for each trail compared lo graminoid species $(p<0.05$ : denoled by $*$ ). Also shown are the pooled meem ( \pm SE) lor the species used in the Barllell el al. (2012b) model sampled from two separate locations: a common garden near University of California I os Angeles (UCI A: annual rainfall $=450 \mathrm{~mm}$ ) and a tropical forest plant community at Xishuangbanna Bolanic Garden in China (XTBG: annual rainlall = $1532 \mathrm{~mm}$ )

\section{(b)

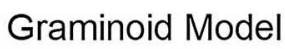

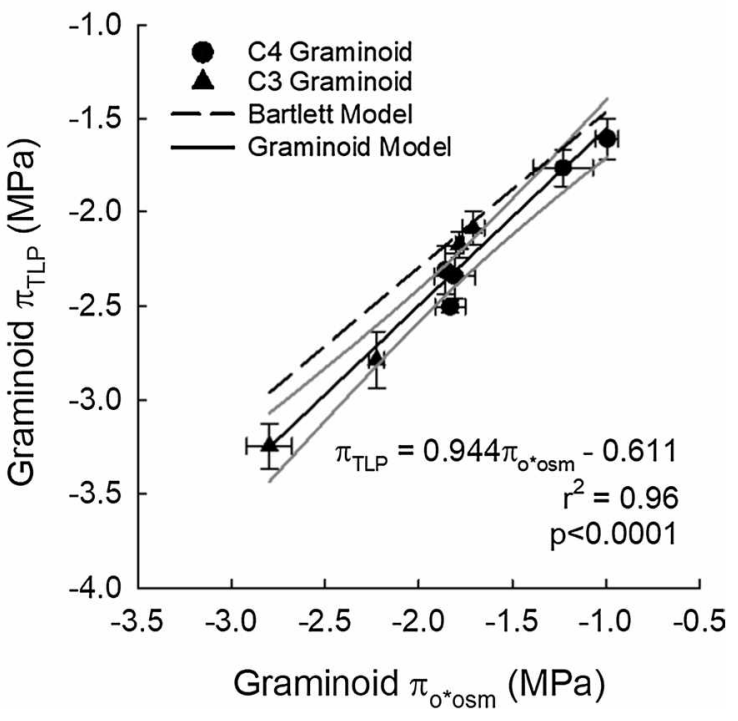

and subshrubs. b The linear model including only graminoid species also skes not viller signilicantly from the Batrletl model (dished line) which falls within the $95 \%$ C. of the slope (0.7743554, 1.1086195) and intercept $(-0.9190000,-0.30 .34649)$ of the graminoid model shown here (black line: grey line represents the $95 \%$ CI). No significant relationship was found for forts/subshruls alone. Symbols represent pholosynthetio pathwaly (C4 vs. (3). Bi-diredional error bars represent standaral error

sites characterized by high annual rainfall. This relationship was driven by the wet extremes of a species distribution as there was only a moderately significant relationship between graminoid $\pi_{0^{*}}$ osm and the 5 th quantile of MAP $(p=0.08)$. Temperature was not a significant predictor of graminoid $\pi_{0^{*} \mathrm{osm}}$ When PFTs were combined, however, the only significant predictor of $\pi_{0}{ }^{*}$ osm $n$ was temperature; a weak positive relationship $\left(r^{2}=0.18 ; p=0.04\right)$ was observed hetween $\pi_{0^{*} \text { osm }}$ and the 5 th quantile of temperature during the wettest quarter of the year. Given that most precipitation in grasslands falls within the spring/summer growing season (Rosenberg 1987), this hioclimatic envelope parameter represents the coldest growing season temperature extremes a species can tolerate. A positive relationship indicates that $\pi_{0, *_{15 \mathrm{~m}}}$ is more negative for species capahle of growing in areas with low growing season temperatures. No significant trait $\times$ climate relationships were ohserved for forbs/subshrubs scparately.

\section{Discussion}

\section{Osmometer method validation}

I.cal hydraulic traits, such as $\pi_{0}$ and $\pi_{\mathrm{TLP}}$ of trees are well correlated with spatial variability in anmual moisture 

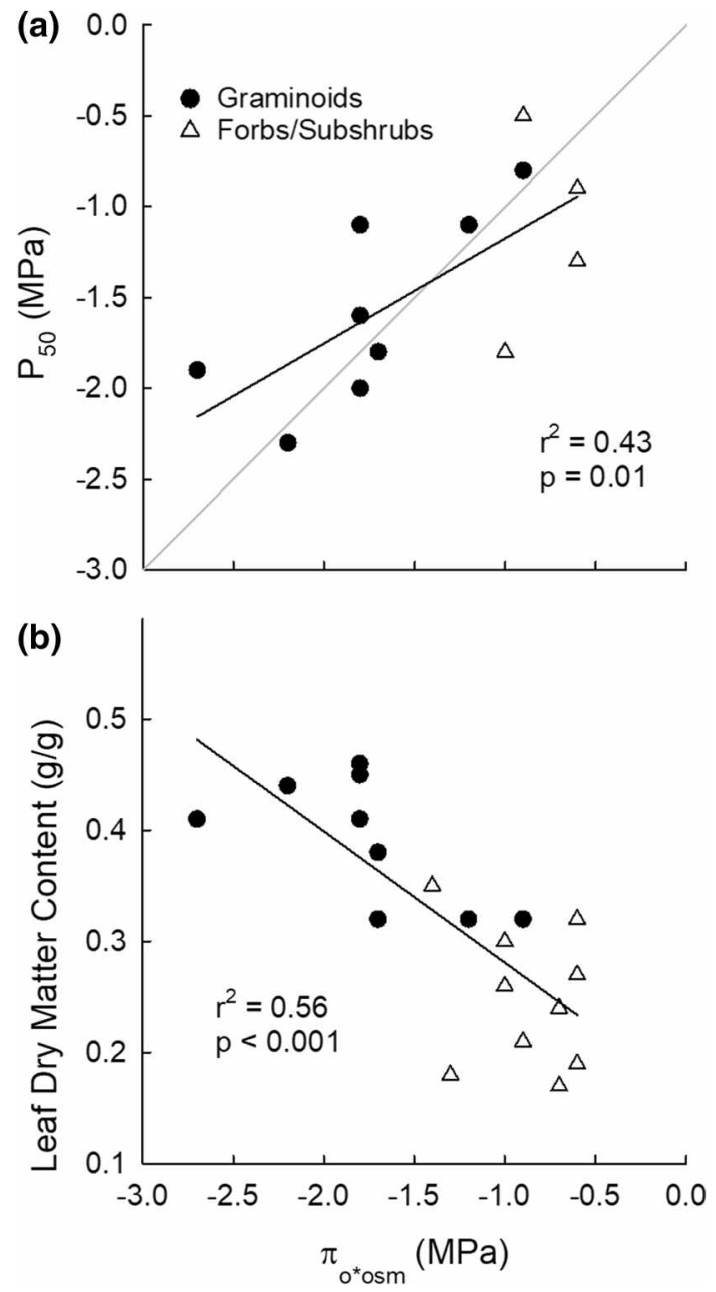

Fig. 6 Osmotic potential al lull lurgor can be rapidly estimaled lrom a vapour pressure osmomeler $\left(\pi_{4, k_{i} \text { m }}\right)$ and is correlated with ol her mechanistic plant traits such as, a the leaf water potential at $50 \%$ loss of hydraulic conductance $\left(\mathrm{P}_{; 0}\right)$ and $\mathbf{h}$ leat dry matter content (I.DMC). The $1: 1$ line is shown as a grey line

availability as well as species distributions across moist and dry hiomes (Bartlett et al. 2012a). The osmometer method for rapidly estimating these traits in woody species has facilitated community-scale surveys of leat-level drought tolerance in several forest ecosystems (Bartlett et al. 2012h; Marechaux et al. 2015); however, concerns about the utility of this method for estimating osmotic potential at full turgor of thin leaves with large midribs (c.g. graminoids) have prevented its application to a wide range of plant functional groups. Several of the graninoid species surveyed in this study have large leal midribs, a characteristic that has the potential to diminish the proportion of extra-xylary water in the sample placed in the osmoneter chamber. Considering that xylem typically contains lower sugar concentrations than other cells in the lear (Peuke et al. 2001), the inclusion of the midrib in a sample could lead to an overestimation of

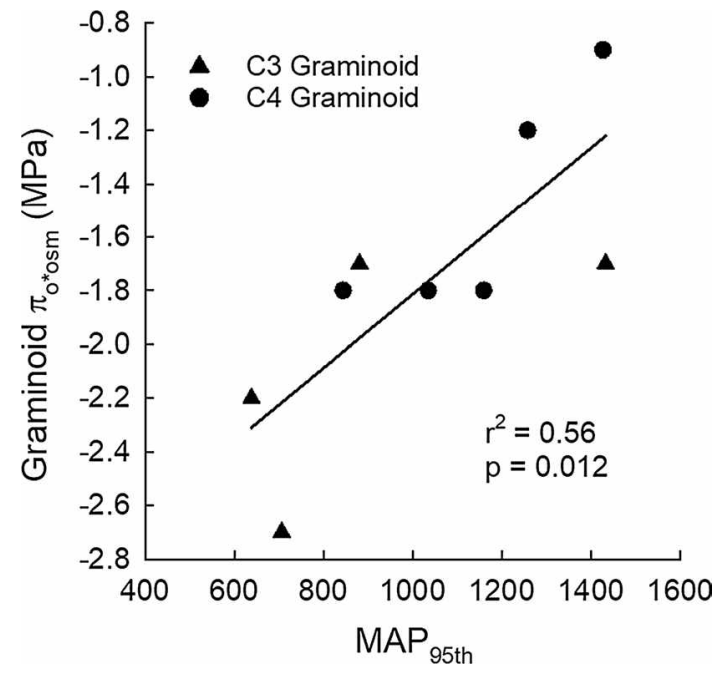

Fig. 7 Mean annual precipitation at the wettest extremes of a species slistribution (MAP, ${ }_{4511}$ ) explained a signilicant portion of inter-

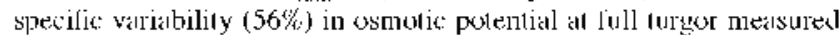
with an osmoneter $\left(\pi_{0} 0_{m}\right)$. A pusitive relationship indicales that species with lower $\pi_{\text {erosm }}$ (more negative) are found in elrier regions of the central US. The wet extreme (i.c. 95th quantile) suggests that resource allocation to drought tolerance (i.c. low $\pi_{t, * \text { and }}$ ) is leneficial alone an ariklity geradient only until waller becones less limiting. al which point more mesic species wilh higher growih rales oulconpele xeric: species. At the dry exlreme ol species bionlimalic envelopes (5th quantile). $\pi_{0^{+}}$osm was only moderately significantly correlated with precipitation during the wettest quarter of the year $(p=0.08)$

$\pi_{0}$ when using an osmonece compared 10 estimates from $p$-veurves (Barletl cl al. 2012b); however, we found no cvidence of this potential bias anong the species we sampled. We observed a significant relationship between osmotic potential at full turgor measured with an osmometer $\left(\pi_{0^{*} \text { osm }}\right)$ and $y-l^{\prime}$ curves $\left(\pi_{0^{*} \mathrm{pv}}\right)$ with all graminoid species talling along the 1:1 line (Fig. 2). A large midrih does not necessarily mean there is a larger proportion of xylem conduits relative to solute-rich mesophyll cells. For instance, large midribs typically have multiple vascular bundles that are similar in size and density to bundles outside of the midrih (Fig S2; also see Evert and Eichhorn 2013). The midrib also has a large amount of parenchyma tissue which contrihutes to total leaf osmotic potential at full turgor. Thus, the inclusion of the midrih may not necessarily lower the proportion of extra-xylary water in a sample.

The slope and interecpt of the relationship shown in Fig. 2 is not significantly different from the relationship presented by Barllctl el al. ((2012b)-Fig. 2, within). This relationship differs significantly from a 1:1 relationship indicating clear bias in osmonetry. Such bias is expected in osmoneter measurements of $\pi_{0}$ duc to the net eflect apoplastic dilution and cell wall dissolution (Barllel ct al. 2012b). Rupturing of plant cell walls during sample processing causes water from the apoplast to dilute the sanple leading to overestimations 
of $\pi_{0}$. Additionally, underestimation of $\pi_{0}$ can occur as disturbed cell wall materials dissolve into the sample solution. We accounted for these opposing effects following $\mathrm{Fa}$. 1 and found a 1:1 relationship between measured and predicted $\pi_{0^{*} \mathrm{csm}}$ (Fig. 3), which is in line with measurements on leaves from woody species (Bartlett et al. 2012b). This highlights the robustness of this method as well as the importance of considering species-specific leaf vein networks and the net effect of apoplastic dilution and cell wall dissolution, which might change the fitted regression across leaf types.

We provide evidence that the osmometer method developed by Bartlett et al. (2012b) can be used to estimate leaf turgor loss point in herbaceous species commonly found in central Us grasslands:

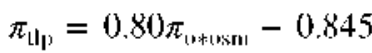

Not only was the relationship between $\pi_{\mathrm{TLY}}$ and $\pi_{\mathrm{e} * \mathrm{esm}}$ statistically significant (Fig. 4a), the model parameters were nearly identical to those presented by Bartlett et al. (2012b) for woody species, suggesting the same linear model can be applied across plant functional types. The striking similarity between the 'Grassland' and 'Bartlett' models is likely a result of: (1) the similar range in drought tolerance assessed in the two studies (Fig. 5); (2) the fact that this method samples similar proportions of mesophyll tissue despite anatomical differences between dicots and monocots; and (3) the dominamt role of osmotic potential at full turgor in explaining turgor loss point across all plants at a global scalc (Bartlell et al. 2012a), and perhaps more so across plant functional types within comnuntities (Fig. 1). Our results show that $72 \%$ of the variation in $\pi_{\mathrm{TL} . \mathrm{F}}$ across all species and $96 \%$ of the variation in $\pi_{\text {TI }}$ of granninoids were explained using the osmonecer method, providing strong sopport for the validity of this technique both across functional groups and within graminoids. The lack of a correlation between $\pi_{\mathrm{TLP}}$ and $\pi_{\mathrm{v}^{*} \mathrm{cos}}$ for forbs/subshrubs may be due to the snaller range in $\pi_{\mathrm{TLP}}$ and $\pi_{\mathrm{C}^{*} \text { oSm }}$ values sanpled. Given that forb species were all measured within the same site (HPG), we recommend additional measurements of $\pi_{\mathrm{TLP}}$ and $\pi_{\mathrm{v}^{*} \mathrm{osm}}$ of forb species across hroad spatial aridity gradients. We suggest caution in interpreting $\pi_{\mathrm{o}^{*} \mathrm{osm}}$ of forh species until additional results on this growth form have been reported. We recommend using the following linear model for estimating leaf turgor loss point from $\pi_{\mathrm{o}^{*} \mathrm{som}}$ of common $\mathrm{C} 3$ and $\mathrm{C} 4$ grass species:

$\pi_{\mathrm{tlp}}=0.944 \pi_{\mathrm{o} * \mathrm{osm}}-0.611$

\section{Mechanistic value of $\pi_{0}$}

This rapid measure of leaf drought tolerance for herbaceous species is especially uselul it these traits can help us understand the ecological stratcgies of plants, which are often identilied through analyses of trait covariation (Wright et al.
2004). We observed a negative relationship between $\pi_{\mathrm{e}^{*} \mathrm{esm}}$ and I.JMC, a commonly measured leal trail indicalive of resource conservation strategies and leaf consiruction costs (Poorler and Garnier 1999) (Fig. 6). L arge values of I IJMC can result from either a large structural investment in leat tissue and/or high concentrations of non-structural carbohydrates. Structural investments are generally considered to result from extensive cell wall investment, such as thickwalled xylem or a large proportion of small diameter vessels. The negative relationship we observed likely reflects both components of LDMC. We would expect plants with more negative $\pi_{0 * * \text { osm }}$ to have a higher concentration of nonstructural carbohydrates or other osmolytes. In addition, especially in ecosystems with more severe or persistent water stress, plants that invest in more negative $\pi_{0^{*}{ }^{*} \text { sstu }}$ (i.e. lower turgor loss point) tend to further bolster their drought tolerance by investing in xylem that is resistant to hydraulic railure (7hu el al. 2018), which is characterized by conduits with thick walls relative to their lumen diameler (Blackman el al. 2010). Indeed, we did lind a negative relationship belween I.DMC and resistance 10 hydraulic failure $\left(\mathrm{P}_{50}\right)$, which may reflect this investment in xylen. We also observed a signilicant relationship he1ween $\pi_{0^{*}, 4 s+1}$ and $P_{50}$ a valuable trail for delining hydraulic salety vs. efliciency tradeolls and re-growlh capabilitics of grasses following drought (Ocheltrece al, 2016). Leal resistance to hydraulic lailure (i.e. $P_{s 0}$ ) is largely decrmined by leal vein archiceture (Scolfoni et al. 2011); thus, the osmoneter mehod can provide hoth a valuahle proxy for $\pi_{\mathrm{TL}}$ as well as information about aspects of drought tolerance more closely associated with leaf structural investments (LDMC and $\mathrm{P}_{50}$ ).

Trait-environment relationships are key for understanding species responses to climate change (Suding et al. 2008). In forested biomes, lower values $\pi_{0}$ are associated with high aridity (Bartlett et al. 2012a; Zhu et al. 2018). For herbaceous plants, identifying climate variahles that explain the distributions of species traits can be more difficult given the ahility of these plants to occupy microsites within a landscape (Ricklefs and Latham 1992). Despite these potential limitations, we did find significant trait-environment relationships for $\pi_{0 *^{*}, \mathrm{sm}}$ of graninoids and PFTs combined. Graminoid species that more exclusively occupy xeric regions (low MAP) tend to have lower $\pi_{0 * *_{1 \mathrm{sm}}}$ (Fig. 7) suggesting that low $\pi_{0^{*}, \mathrm{sm}}$ helps plants 10 survive and reproduce where water is limiling, as observed for woody species (Barllell el al. 2012a); however, MAP al the driest extremes of graminoid species distributions ( $\mathrm{MAP}_{\mathrm{s}_{11}}$ ) was not signilicantly correlated with $\pi_{0^{*} \text { osm }}$, while MAP of the wellest extrenes was (Fig. 7); this indicates that the distribution of drought tolcrance traits for graninoids may be decrmined by competitive pressures that are maximized at the welter end of their distribution where nore acquisitive laster growing species dominate grassland communities. Allocating 
resources 10 lower $\pi_{0^{*} \text { osm }}$ is indeed advantageous in drier climates; however, it may prevent graminoid species from inhabiting mesic areas where the cosis of such strategies (slower growh rales) ontweigh the benelits.

Across functional types, temperature was the only significant climatic predictor of $\pi_{0 * \mathrm{csm}}$. Specifically, temperature of the wet season for the coldest regions of a species distribution explains only $18 \%$ of the variability in $\pi_{\mathrm{e}}{ }^{\mathrm{os} m}$ across PFTs. This significant, albeit weak, relationship may simply reflect functional type differences (graminoids vs. forbs/subshrubs; Fig. 5) and the temperature constraints on the geographic distribution of C4 vs. C3 plants (Sage and Monson 1999; Edwards and Still 2008) or adaptations for freezing tolerance (Liu and Osborne 2008). The lack of any significant trait $\times$ climate relationship for forbs/subshrubs highlights the potential lack of utility of this trait for underslanding drought responses of these functional types, which iend 10 rely more on deep roots rather than drought-1olerant leaves (Weaver 1958).

Until additional studies evaluate the relationship between

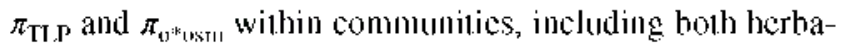
ceous and woody-dominated ceosystens, it will remain unclear to what extent the tight coupling of $\pi_{\text {TI.P }}$ and $\pi_{0, * \text { usm }}$ across broad geographic seales and phylogenctic groups (sensu Barlet el al, 2012b and (his sludy) is representalive of: (1) convergent, bul parlly independent responses of both $\pi_{\mathrm{ILP}}$ and $\pi_{\mathrm{e}^{*} \text { osm }} 10$ environmental gradients in space and time, or (2) stringent biophysical or ecological constraints on covariance hetween $\pi_{\mathrm{TLP}}$ and $\pi_{\mathrm{o}^{*} \mathrm{os} m}$ that operate independent of the spatial or phylogenetic scope of sampling. In other words, caution must be applied when interpreting the functional equivalence of $\pi_{\mathrm{TLP}}$ and $\pi_{\mathrm{o}^{*} \text { osm }}$ among species within any given community. Additionally, although $\pi_{\mathrm{TLP}}$ and $\pi_{\mathrm{c}^{*} \mathrm{osm}}$ represent promising traits for capturing differences in the ability of plants to maintain function and keep tissues alive at low water potentials, they do not capture drought-avoidance strategies that enable plants to maintain high leaf water potential through water conservation or deep rooting profiles (Levitt 1980; Mitchell et al. 2016). Further-

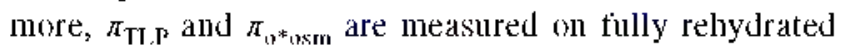
plants, which hails to capture the trait plasticity exhibited by some species when partially dehydrated. For exanple, $\pi_{\mathrm{TI}}$. call change by $>1.0 \mathrm{MPa}$ in Jumperts monosperma within scveral hours, primarily due to osmotic adjustment (Meimzer et al., 2014). On a global scalc, however, osmotic adjustment typically accounts for up to a $0.5 \mathrm{MPa}$ change in $\pi_{\mathrm{TT} . \mathrm{P}}$ (Bartlell el al., 2014), and has litle influence on species" ranks with respect to leal-level drought tolerance, but there are clearly exceptions that should be considered when interpreting $\pi_{\mathrm{TLP}}$ and $\pi_{0^{*} \text { osm }}$ as indices of plant responses 10 drought.

In summary, leaf-level drought tolcrance of herbaccous species can be measured accurately and rapidly using the osmometer method. We provide evidence that $\pi_{\mathrm{o}^{*} \text { osm }}$ predicts
$\pi_{\mathrm{TLP}}$ of herbaceous species from a lincar moded nearly identical to that of woody species $\left(\pi_{\mathrm{tlp}}=0.80 \pi_{0^{*} \text { osm }}-0.845\right)$ and is well correlated with (wo olher traits indicative of drought. tolerance (I.DMC and $\mathbf{P}_{s 0}$ ) as well as species-specilic distributions across gradients of precipitation. There is an urgent need for rapid techniques to assess plant community-scale drought tolerance (Griffin-Nolan et al. 2018) as a hotter and drier climate will become the norm for many of Earth's ecosystems (IPCC 2013). To make predictions of how different plant functional types will respond to increased drought frequency and intensity, we need to identify baseline metrics of drought tolerance that are comparable across the plant kingdom. The osmometer method makes community-scale surveys of drought tolerance possible, which will improve trait-based predictions of ecosystem responses to climate change and allow for a more integrative understanding of plant functional strategies for dealing with water stress.

Acknowledgements We would like to thank Vicloria Klimkowski. Damiel Spizer, Dan LeCain. Julie Busbey. and Mary Carlson lor belping with slalla collection and three anonymous reviewers lor provisling comments that greatly improwed this manuscript. 'This work was funded lyy the NSF Femerging Frontiers Macrosystem Biology Program (TiF$1137378, \mathrm{EF}-1137363, \mathrm{EF}-1137342$ all $\mathrm{EF}-1137293$ ).

Author contribution statement All aluthors contribuled substantially to Jatia collection and the conception ol the experiment. RJGN and TWO conducted the analyses and wrote the initial draft of this manuscript: other authors provided editorial advice.

\section{References}

Baker M (2016) Is there a reproducihility erisis? $\Lambda$ nature survey lifts the lid on how researchers view the 'crisis' rocking scicnee and whal they think will help. Nature 533(7604):452-455

Bartlelt MK. Scolfoni C. Sack L (2012a) The determinants of leal turinor loss point and prediction of drought tolerance of species and biomes: a global meta-analysis. Ticol I ctt 1.5(5):39:-405

Bartlett MK. Seotioni C, Ardy R. 7hang Y, Sun S. Cao K. Sack I (2012b) Rapid determination of comparative drought tolerance traits: using an osmomeler lo predicl lurgor loss point. Methods Ecol Evol 3(5):\$80-8s8

Bartlett MK, 7hang Y, Kreidler N, Sun S, Ardy R, Can K, Sack J (2014) Cilobal analysis of plasticity in turgor loss point, a key drought tolerance trait. Feol I ctt 17:1580-1590

Bartlell MK. Zhang Y. Yand J el al (2016) Drought lolerance as a driver of tropial foresl assembly: resolving spalial signalures lor multiple processes. Eoolony 97:503-514

Beck J. Boller M. T.rhardt $\Lambda$. Schwanghart W (2014) Spatial bias in the GBIT datahase and its effect on modeling species' geographic distributions. Teol Inf 19: 10-15

Blackman CJ. Brodribb TJ, Jordan (jJ (2010) Leal hydraulic vulnerability is related to conduil dimensions and drought resistance across a diverse range ol woudy angiosperms. New Phylol 188:1113-1123

Brodribb TJ (2017) Progressing from 'functional' to mechanistic traits. New Phytol 215(1):9-11 
Brodrih TJ, Holbrook NM (2003) Stomatal closure during leaf dehydration, correlation with other leaf physiological traits. Plant Physiol 132(4):2166-2173

Dai A (2011) Drought under global warming: a review. WIREs Clim Chalnes 2:45-65

Dai $\Lambda$ (201.3) Increasing drought under global warming in observations and models. Nat Clim Change 3:52-58

[iclwards FiJ. Still CJ $(2008)$ Climate, phylogeny and the ecological distribution ol C4 yrasses. Eool Lell 11(3):266-276

Esperón-kodríguez M. Curran TJ, Camaic IS. Holmann RW, CorręMelrio A, Barraklas VL (201\$) Correlation ol drought trails and the predictability of osmotic potential at full leaf turgor in vegetation from New 7caland. Austral [icol 4.3:397-408

Evert RE. Fichthorn SE (2013) Rawen hiology of plants. Freeman and Co. Chicago. pp 598-5y4

Fiekl CB. Behrenleld MJ, Kanklerson JT. Falkowski P (1998) Primary production of the biosphere: integrating terrestrial and oceanic components. Science 28 ] $(5.374): 2.37-240$

Griftin-Nolan RJ, Bushey JA. Carroll CJW et al (2018) Trait selection and iommunily weighting are key fo understanding enosystem responses to hameing precipilation regines. Funct Eool 00: 1-11. hilps://doi.ory/10.1111/1365-2435.13135

Huxman TT: Smith MD. Fay PA. Knapp AK. Shaw MR. I.oik ML. Smith SD, Tissuc DT, 7ak JC. Weltzin JJ, Pockman WT (2004) Convergence across biomes to a common rain-use efficiency. Nillure 424(6902):651

IPCC (2013) Climale Change 2013. The physial science basis. Working group I contribution to the lifih alssessment reporl of the intergovernmental panel on climate change. Stocker TT. Qin D. Plattner GK. Tignor MMB, Allen SK. Boschung J, Naucls $\Lambda$. Xia Y, Bex V Midgley PM. eds. Cambridge University Press. Cambridge

Karrl TR. Melillo JM. Pelerson TC (2009) Global dimale shange impacts in the United Stales: al stale of knowledge report from the US Giobal Change Rescarch Program. Cambridge University Press, Cambridge

Kikula SB. Richter H (1992) Leal discs or press saps? A comparison of lechnicues for the determination of osmotic polenlials in freezeLhawed leal material. J Exp Bor 43(8): 1030-1044

Knap' $\wedge$ K, Carmoll CJ, Denton ГiM, I a Pierre KJ, Collins SI.. Smith MD (2015) Differential sensitivity to regional-scale drought in six central US grasslands. Occologia 177(4):949-957

Knapp AK. Ciais P. Smith MD (2017) Reconciling inconsislencies in precipilalion-produclivily relalionships: implicalions for climale change. New Phylol 214(1):41-47

Koide RT. Robichaux RH. Morse SR. Smith CM (1989) Plant water status, hydraulic resistance and capacitance. Plant physiological ccology. Springer. New York. p'1 161-18?

Kramer PJ, Boyer JS (1995) Water relalions ol plants and soils. Acaldemic Press. San Diego

Kunkel KE. Slevens LE. Slevens SE el al (2013) Regional Climale Trends and Scenarios for the U.S. National Climate $\Lambda$ ssessment. Part 4. Climate of the U.S. Gircat Plains. NOA $\wedge$ Technical Report NTSSDIS 1 42-4, 82

Levilt J (1980) Responses ol plents to environmental slresses. Volume ll. Waler. radiation. salt, and oher stresses. Academic Press. New York

I.iu M7, Osborne CP $(2008)$ I caf cold acclimation and freczing injury in C3 and C4 grasses of the Mongolian Plateau. J Jixp Bot $59(15): 4161-4170$

Marechaux 1, Bartlell MK. Sack L. Baralolo C., Engel J, Joelzjer E, Chave $\mathbf{J}(2015)$ Drought tolerance as predicted by leal water polential at turgor loss poinl varies strongly across species within an Amazonian forest. Funct Ficol 29(10): 1268-1277

Marechaux I. Bartlett MK, Gaucher P. Sack I. Chave J (2016) Causes of variation in leaf-level drought tolerance within an Amazonian lorest. J Plant Hydraul 31(3):e004
Mar1 KB. Veneklatas EJ, Branley H (2016) Osmolic polential al lull Iurgor: an easily measurable lrail to belp breeders seleal for drought tolerance in wheat. Plant Breed 135(3):279-285

Meinzer JC. Woodrufti [DR. Marias [D[. McCulloh KA. Sevanto S (2014) Dynamics of leaf water relations components in cooccurring iso-and anisohydric coniler species. Plant. Cell Enviroll $37(11): 2577-2586$

Meinzer FC. Woodrull DR, Marias DE. Smith DD, MiCulloh KA. Howard AR. Magedman AI. (2016) Mapping 'hydroscapes' along the iso-to anisolydric continum of stomatal regulation of planl walter slaltus. Eicol Lell 19(11):1343-1352

Mitihell PJ. O grakly AP, Pinkard EA el al (2016) An ecoclimalio lranework for evaluating the resilience of vegelation to waler deficit. Glob Change Biol 22(5): 1677-1689

Noy-Meir I (1973) Desert ecosystems: environment and producers. Annu Rev Jicol Syst 4(1):25-51

Ochellree TW. Nipper JB. Prasad PV (2016) A salely vs elliciency lrakle-oll identilied in the hydralic patbway of yrass leaves is lecoupled lrom phorosynthesis. stomalal condluctance and precipitation. New Phytol 2 10(1):97-107

Paine CT. Deascy $\Lambda$, Duthic $\Lambda B(2018)$ Towards the general mechanistic prediction of community dynamics. Funct Ficol $32: 1681-1692$

Peuke AD, Rokilla M. Zimmer mann U. Sohreiber L. Halase A (20k1) Simulianeous measurement ol waller llow velorily and solule transport in xylem and phloem of adult plants of Ricinus communis ower a daily time course by nuclear magnetic resonance spectrometry. Plant, Cell [inviron 24:49]-503

Poorler H. Gamier E (1949) Ecological signilioance ol inherent varialion in relative yrowth rale alnd its components. Halndbook Funct Plant $[\mathrm{icol} 20: 81-120$

Reich PB (2014) The world-wide "fast-slow plant economics spectrum: a traits manifesto. J Ficol $102(2): 275-.30 \mathrm{~J}$

Ricklefs RE. Lathan RE (1942) Inlercontinental correlation of geographical ranges suggests stasis in ecological Iraits of relict genera of lemperale perennial herbs. Am Nal 139(6):1305-1321

Rosenterg NJ (1987) Climate of the Great Plains region of the United States. Gireat Plains Quarterly, 22-32

Sack I. Melcher PJ, 7wicniceki M A. Holtrook NM (2002) The hydraulic conduclance of the angiosperm leal lamina: a comparison ol three measuremenl methods. J Exp Bol $53(378): 2177-2184$

Schulte PJ. Hinckley TM (1985) A comparison of pressure-volume curve data analysis techniques. J $\Gamma x_{p}$ Bot $36(16): 1590-1602$

Sage RF. Monson RK (1999) C4 plant hiology. Neademic. New York

Soufloni C. Rawls M. McKown A. Cochard H. Sack L (2011) Decline of leal hydratic conduclance with debydration: relálionship to leal size and venation architecture. Plant Physiol. https:/doi. 0 rg/10.1104/10.111.173856

Shipley B, De Bello J. Cornelissen JH, I alibertê Г.. J aughlin DC, Reich PB (2016) Reinloring loose loundation slones in Irailbased planl ecolony. Oecologia 180(4):923-931

Suding KN, Laworel S, Chapin FS et al (2008) Scaling environmental change through the community-level: a trait-based response-and-effect framework for plants. Gilob Change Biol 14(5): $1125-1140$

Turner NC (1988) Measurement ol planl waler stalus by the pressure chamber lechnique. lrig Sci 9(4):289-30s

Weaver JE (1958) Classitication of rool systems of lorbs of grassland and a consideration of their significance. Tocology $39(3): 39,3-401$

Wright J. Reich PB. Westoby $M$ et al (2004) The worldwide leaf ceonomics spectrum. Nature 428(6985):821

Zhu SD. Chen YJ. Ye Q et al (2018) Leal turgor loss point is correlated with drought tolerance and leal carbon economics traits. Tree Physiol. hltps://doi.org/10.1093/treephys/pyol3 